\title{
Cadmium pathways in an exploited intertidal ecosystem with chronic cadmium inputs (Marennes-Oléron, Atlantic coast, France)
}

\author{
Jacques Pigeot ${ }^{1, *}$, Pierre Miramand ${ }^{1}$, Thierry Guyot ${ }^{1}$, Pierre-Guy Sauriau ${ }^{2}$, \\ Denis Fichet ${ }^{1}$, Olivier Le Moine ${ }^{3}$, Valérie Huet ${ }^{1}$ \\ ${ }^{1}$ Laboratoire de Biologie et Environnement Marins (FRE CNRS 2727), Université de La Rochelle, Avenue Michel Crépeau, \\ 17042 La Rochelle Cedex 01, France \\ ${ }^{2}$ Centre de Recherche sur les Ecosystèmes Marins et Aquacoles (CREMA, UMR10 CNRS-IFREMER), BP 5, \\ 17137 L'Houmeau, France \\ ${ }^{3}$ Laboratoire Environnement Ressources des Pertuis Charentais (LER.PC), IFREMER Ronce-les-Bains, BP 133, \\ 17390 La Tremblade, France
}

\begin{abstract}
The Marennes-Oléron Bay is subject to chronic pollution by cadmium (Cd) from the Gironde watershed. An ecosystem approach was used to study the fate of cadmium in the different biological compartments. The median Cd concentration was $0.4 \mu \mathrm{g} \mathrm{g}^{-1}$ dry weight for the 63 benthic species measured. When combined with the respective biomasses for the different species studied, we estimated that $7 \mathrm{~kg}$ of $\mathrm{Cd}$ is partitioned into the soft tissues of the benthic species in the bay. The majority of this cadmium was distributed between primary producers, mainly microphytobenthos $(40 \%)$, and suspension-feeders, mainly oysters $(40 \%)$. All other benthic species measured were associated with negligible masses of Cd. Two trophic levels contained $98 \%$ of the Cd: $3 \mathrm{~kg}$ was partitioned into primary producers (of which $77 \%$ is associated with the microphytobenthos) and $3.2 \mathrm{~kg}$ of Cd was distributed among all suspension feeders. The carnivores, including scavengers, concentrated less than $0.2 \mathrm{~kg}$ of $\mathrm{Cd}$, suggesting an absence of biomagnification of $\mathrm{Cd}$ in the trophic food web of the bay. The microphytobenthic compartment was estimated to control the largest quantity of $\mathrm{Cd}$ (ca. $188 \mathrm{~kg} \mathrm{yr}^{-1}$ ), suggesting an important role for the microphytobenthos in the biogeochemical cycle of $\mathrm{Cd}$ in the bay. The quantities of $\mathrm{Cd}$ associated with annual biological production in other biological compartments were low: $2 \mathrm{~kg} \mathrm{yr}^{-1}$ for eelgrass which could represent a vector of $\mathrm{Cd}$ transfer to winter populations of Brent geese and $1.4 \mathrm{~kg} \mathrm{yr}^{-1}$ for all suspension feeders, principally the cultivated Pacific oysters $(64 \%)$ representing a vector of Cd transfer to humans. An ecosystem-wide budget for the quantities of $\mathrm{Cd}$ present in all the biological and physical compartments showed that the majority of $\mathrm{Cd}(1 \mathrm{t})$ is trapped in the upper $5 \mathrm{~cm}$ of the bay sediments, representing a potential risk for the oyster and shellfish cultivation in the bay.
\end{abstract}

KEY WORDS: Macrophytes - Microphytobenthos - Macrofauna - Cadmium - Bioaccumulation · Trophic food web · Marennes-Oléron Bay

Resale or republication not permitted without written consent of the publisher

\section{INTRODUCTION}

The Marennes-Oléron Bay represents the coastal endpoint of a continuum of $\mathrm{Cd}$ pollution which begins $450 \mathrm{~km}$ upstream, in a small tributary of the Lot River, called the 'Riou Mort' (Jouanneau et al. 1990, Lapaquellerie et al. 1995, Grousset et al. 1999) (Fig. 1). The cadmium contamination originates from a discharge of mine treatment waste by the ore processing plant ' Vieille Montagne' that is located on the Riou Mort river, in Decazeville (Aveyron, France) (Grousset et al. 1999). This processing plant has been discharging waste into the tributary for many decades, up to $60 \mathrm{~kg}$ of cadmium per day. In addition, runoff, enriched in cadmium from the unstabilised and exposed tailings of the processing plant, flows directly into the Riou Mort. In 1986, the pro- 


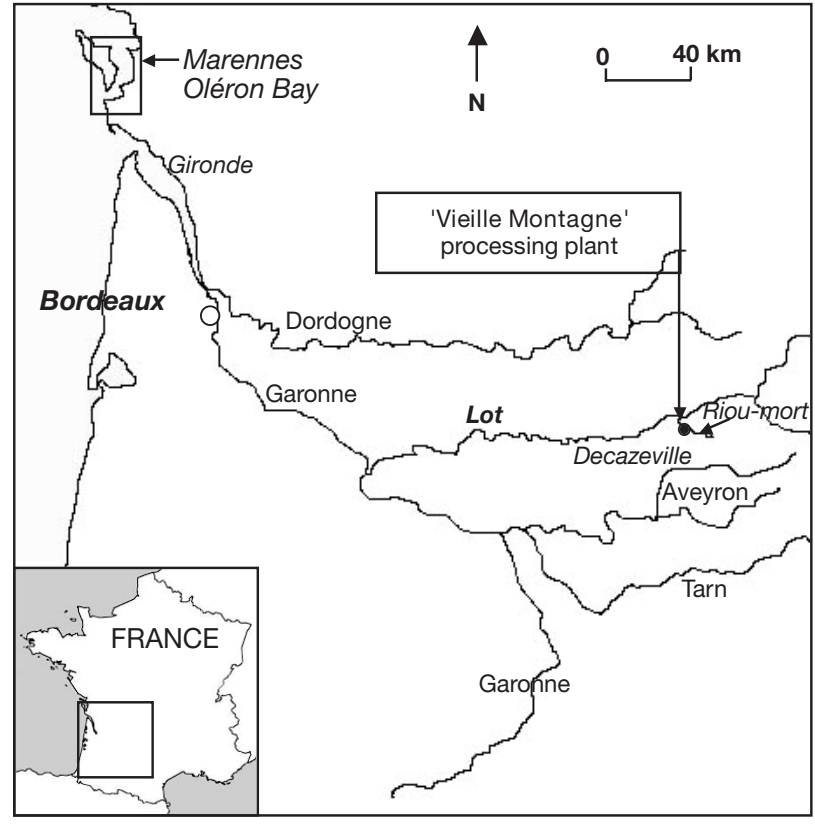

Fig. 1. Location of the major $\mathrm{Cd}$ output linked to mining activities within tributaries of the Garonne River, $450 \mathrm{~km}$ upstream of the Marennes-Oléron Bay.

cessing plant stopped metal production, the tailings were isolated, and the runoff water treated. Nonetheless, the remaining cadmium mass trapped in the sediments of the Lot River was estimated to be nearly $200 \mathrm{t}$ in 1991 (Lapaquellerie et al. 1995). The Garonne River and Gironde Estuary, which are downstream from the Riou Mort and the Lot River, have been contaminated through the flux of eroded, contaminated bottom sediments (Latouche 1988, Boutier et al. 2000). Even if the Cd fluxes have decreased since 1985 as distance from the Gironde Estuary increased (RNO 2000), they remain important, and are currently estimated at 4 to $5 \mathrm{t}$ of dissolved cadmium per year. In the estuarine environment, cadmium sorbed on sediment particles may desorb as the water salinity increases (Latouche 1988, Lapaquellerie et al. 1996, Boutier et al. 2000). Thus, in the plume of the Gironde Estuary Cd is preferentially in a dissolved form that has a higher bioavailability for living organisms, including shellfish species that were commercially-grown in the estuary, such as the Pacific oyster, Crassostrea gigas. Since 1996, high cadmium concentrations measured in oysters from this estuary have led to a prohibition on the commercialisation of this bivalve for the entire Gironde estuarine zone (RNO 2000).

Depending on meteorological conditions in the Gulf of Biscay and the fluvial flow, a portion of the Gironde estuarine plume reaches Marennes-Oléron Bay (Lazure \& Jégou 1998), and 400 to $500 \mathrm{~kg}$ of dissolved $\mathrm{Cd}$ enters the Marennes-Oléron Bay each year through the 'Pertuis d'Antioche' (Antioche Straits) north of the island of Oléron (Boutier et al. 2000). The bay is a well-studied system in terms of biological compartments (Sauriau et al. 1989, Sautour \& Castel 1998) and hydrological (Héral et al. 1984, Soletchnick et al. 1998) and sedimentary processes (Raillard \& Ménesguen 1994), making it suitable for studies of the fate of $\mathrm{Cd}$ at the ecosystem level. It has been the focus of study for many years because of its importance in the shellfish industry in France (Héral et al. 1989, Goulletquer \& Héral 1997). Marennes-Oléron Bay, which has an annual production of $30000 \mathrm{t}$ of oysters from a stock of more than $100000 \mathrm{t}$, is also a major zone for oysterspat collection, and a site traditionally important in the refining of oysters in 'claires' located in salt-marsh ponds (Goulletquer \& Héral 1997). The bay has a large ecological status as demonstrated by a recent macrofaunal inventory which enumerated more than 300 macrofauna species in the bay (de Montaudouin \& Sauriau 2000). In addition, the bay is an important regional centre of tourism, where the population increases by 10 -fold during the summer season (to about 100000 people).

Until recently, the fate of $\mathrm{Cd}$ in the Marennes-Oléron Bay was only investigated in the context of monitoring studies for the Cd content in Crassostrea gigas. Since 1979, this oyster species has been used as a bioindicator species in a long-term monitoring study as part of the French National Monitoring Network (RNORéseau National d'Observation: www.ifremer.fr/envlit/ index.htm) for the quality of the marine environment (RNO 1988, 2000, 2004). No other data on the amount of Cd contamination has been available for other species in the bay. The present study implements an ecosystem approach in place of bioindicator species. With this approach, a large number of representative species from the different trophic compartments in the bay are analysed for $\mathrm{Cd}$ content to study the distribution of $\mathrm{Cd}$ in the food web of the bay. The objectives of this study were: (1) to calculate the quantities of $\mathrm{Cd}$ partitioned at a given time into each biological component from primary to secondary producers, (2) to calculate the partitioning of $\mathrm{Cd}$ by each trophic level, and (3) to evaluate the role of different organisms in terms of identifying which biological compartments are likely to mobilise important quantities of $\mathrm{Cd}$ within the trophic networks of the Marennes-Oléron Bay.

\section{MATERIALS AND METHODS}

Description of the Marennes-Oléron Bay. The Marennes-Oléron Bay is located on the south-western Atlantic coast of France, north of the Gironde Estuary and south of the Charente River estuary (Fig. 1). The bay is bounded to the west by Oléron Island, to the 
north by a line extending from Saumonards Point on Oléron Island to Fouras on the continental side (west to east) and to the south by Maumusson Strait (Fig. 2). Dissolved $\mathrm{Cd}$ concentrations in the bay are in the order of $20 \mathrm{ng} \mathrm{l}^{-1}$ (B. Boutier pers. comm.), and the concentrations of particulate $\mathrm{Cd}$ are $0.26 \mathrm{\mu g} \mathrm{g}^{-1}$ (Pigeot 2001). The total surface area, including the intertidal and subtidal zones, is in the order of $180 \mathrm{~km}^{2}$ (Sauriau et al. 1989, Soletchnik et al. 1998); the intertidal zone has a surface area of $96 \mathrm{~km}^{2}$ (Soletchnik et al. 1998). In this

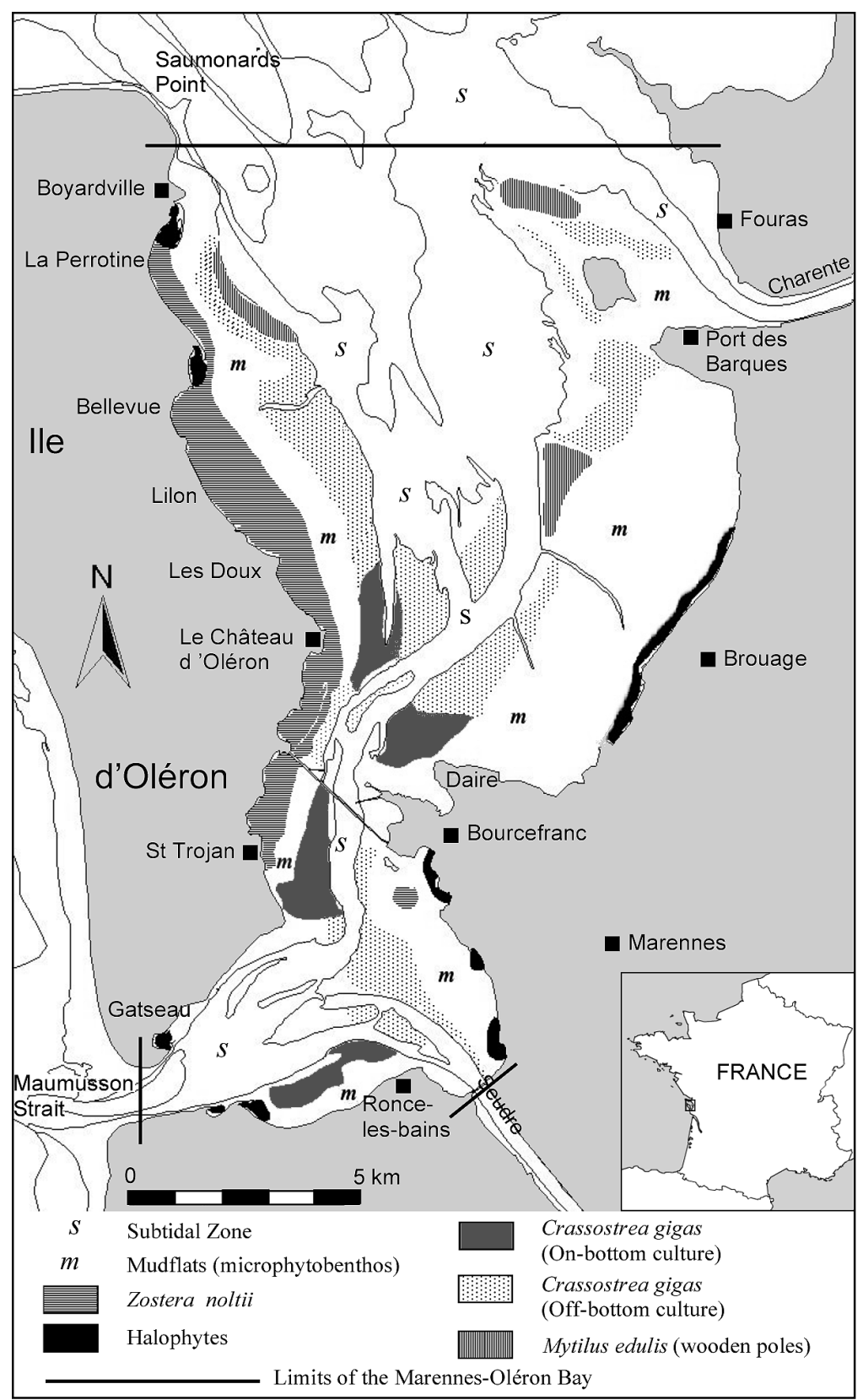

Fig. 2. Marennes-Oléron Bay at low tide, showing the extent of bare mudflats, eelgrass meadows, oyster parks (with off-bottom and on-bottom cultures), mussel poles and salt-marsh vegetation areas bay, the major portion of the biomass (including cultivated shellfish) is located in the intertidal zone and thus, for the purposes of our study, we have concentrated our sampling efforts in this zone.

Sediments of the bay range from pure mud to sandy mud with some limited areas of rocky outcrops (see Sauriau et al. 1989 for a detailed map). The intertidal zone includes: (1) bare mudflats dominated by microphytobenthos which consists mostly of pennate diatoms (Cariou-Le Gall \& Blanchard 1995), (2) some meadows of dwarf eelgrass, Zostera noltii, mainly located on the Oléron Island (Guillaumont 1991, Sauriau \& Kang 2000) and covering a surface area of $8.65 \mathrm{~km}^{2}$ (Pigeot 2001), (3) the upper shore, which forms a border some dozens of meters wide in the most protected zones of the bay, and covers about $1.2 \mathrm{~km}^{2}$ where the halophytes Atriplex (= Halimione) portulacoides and Sarcocornia (= Arthrocnenum) perennis predominate, and (4) shellfishery zones, located in the lower portion of the intertidal area (on-bottom and off-bottom oyster cultivation zones and mussel poles), and covering a surface area of $30 \mathrm{~km}^{2}$ (Fig. 2).

Species sampling at Château Oléron station. We sampled a number of different species, mostly in spring of 1997 (70\% of the samples); the remainder were collected in spring 1998 and 1999. All species were collected by hand at low tide from the rocky and sandy-mud substrates at Château d'Oléron (Fig. 2); this station is representative of the bay with respect to its sedimentary features (predominance of sandy-mud facies) and also for the cadmium concentrations in the oysters (RNO 1995, 2000) which remained stable over the 1997-1999 sampling period in the range of 1 to $4 \mu^{-1} g^{-1}$ dry weight (RNO 2000, 2004). Species have been sampled in the 3 levels of the midlittoral zone. Those organisms that only live at precise locations within 1 level were only sampled at that 1 level; species that occur in several levels of the midlittoral zone were sampled from the level where they had the highest biomass. In total, 63 macroscopic plant and animal species were collected. Microphytobenthos was sampled from sandy-mud sediments from the mid-littoral zone. The types of organisms sampled were: (1) primary producers (microphytobenthos, dif- 
ferent green, brown and red macroalgae and salt marsh plants (leaves and rhizomes were separated) and (2) the consumers as represented by 10 taxa (Porifera, Cnidaria, Polychaeta, Polyplacophora, Gastropoda, Bivalvia, Crustacea, Echinodermata, Ascidia and Teleostei). The 49 consumers are all metazoans and belong to 8 trophic groups, to which 2 other groups for the suprabenthic species were added: the carnivores and the omnivores (Table 1). In addition, the principal subtidal species have been sampled by dredging or trawling in the central channel of the Marennes-Oléron Bay. All species were analysed without depuration.

Separation of the microphytobenthos from the sediments. A sufficient biomass of microphytobenthos for the analyses was collected using the method described by Riera et al. (1996). Surface sediments (1 1 from the upper $2 \mathrm{~mm}$ ) were collected from the mudflats by gently scraping the surface with a plastic spatula. After the sample was transported back to the laboratory, the mud was placed into trays, and covered with a $63 \mu \mathrm{m}$ nylon mesh. A silica gel with granules greater than $63 \mu \mathrm{m}$ in diameter was then spread onto the nylon mesh. This assemblage was placed under artificial light for $48 \mathrm{~h}$ to allow benthic diatoms to migrate from the sediment into the silica gel. After the migration period was complete, the gel was sieved using a second $63 \mu \mathrm{m}$ mesh and the diatoms recovered by centrifugation of the filtrate.

Cadmium analyses. Upon returning to the laboratory, all species were cleaned and any epiphytes removed, and the samples were frozen $\left(-20^{\circ} \mathrm{C}\right)$ until

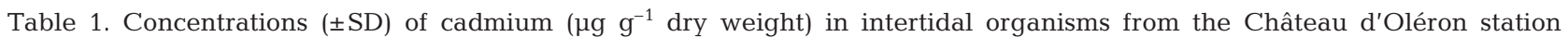
$\left(45^{\circ} 53^{\prime} \mathrm{N}, 1^{\circ} 11^{\prime} \mathrm{W}\right)$ in spring 1997, 1998 and 1999 ( $\mathrm{n}=$ number of replicates). Trophic level: primary producers (pp) and consumers (sus $=$ suspension feeders, car $=$ carnivores, omn $=$ omnivores, her $=$ herbivores, dep $=$ deposit-feeders, sca $=$ scavengers, sdf $=$ suspension-deposit feeders, omn $=$ suprabenthic omnivores, det $=$ detritivores, car $=$ suprabenthic carnivores $)$. Reference sources (Ref.): 1, Purchon (1968); 2, Newell (1979); 3, Turquier (1989); 4, Fish \& Fish (1996)

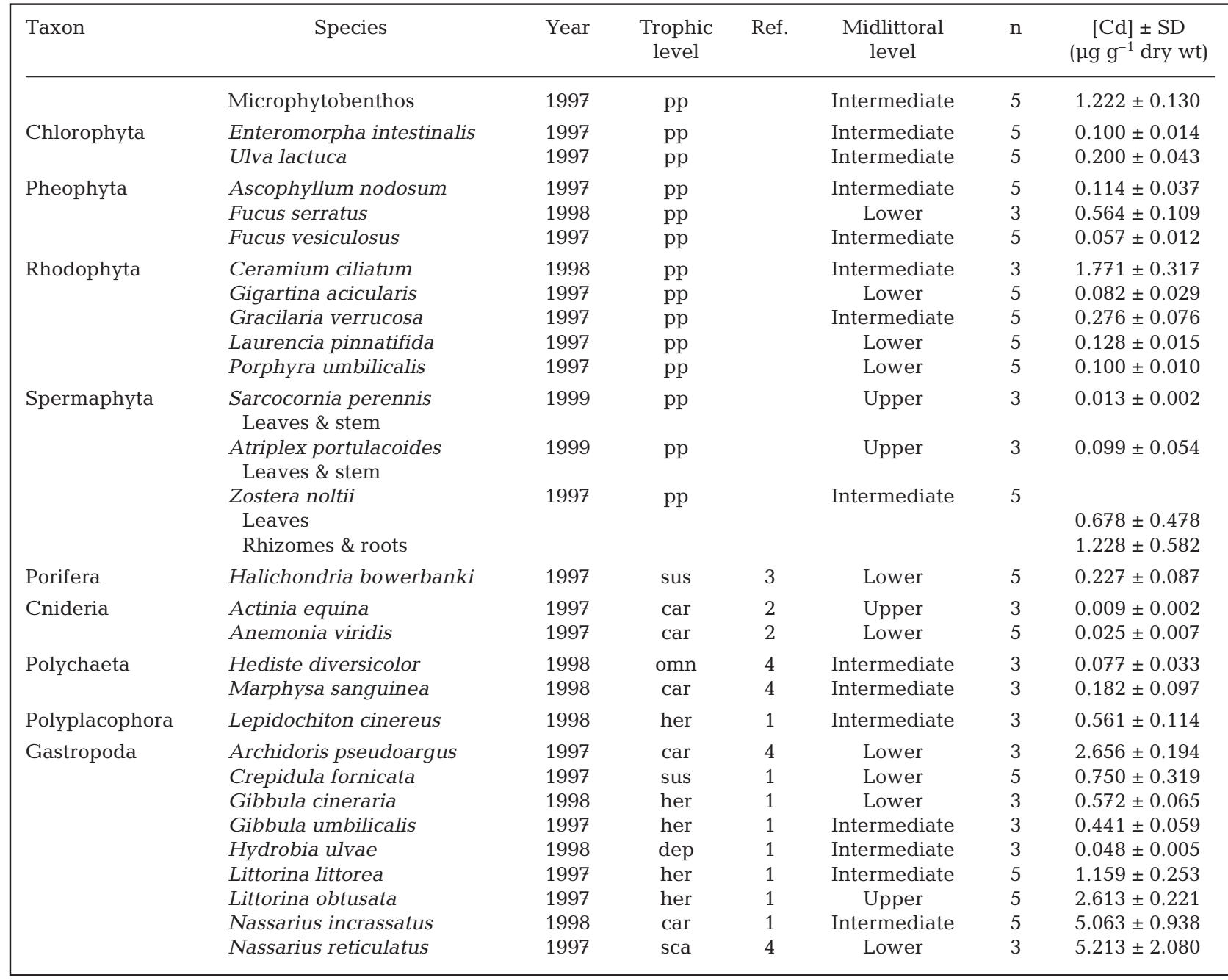


Table 1 (continued)

\begin{tabular}{|c|c|c|c|c|c|c|c|}
\hline Taxon & Species & Year & $\begin{array}{c}\text { Trophic } \\
\text { level }\end{array}$ & Ref. & $\begin{array}{l}\text { Midlittoral } \\
\text { level }\end{array}$ & $\mathrm{n}$ & $\begin{array}{c}{[\mathrm{Cd}] \pm \mathrm{SD}} \\
\left(\mu \mathrm{g} \mathrm{g}^{-1} \text { dry wt }\right.\end{array}$ \\
\hline \multirow{16}{*}{ Bivalvia } & Nucella lapillus & 1998 & car & 1 & Lower & 3 & $9.541 \pm 3.752$ \\
\hline & Ocenebra erinacea & 1997 & car & 3 & Intermediate & 5 & $5.822 \pm 1.389$ \\
\hline & Ocinebrellus inornatus & 1998 & car & 3 & Lower & 3 & $6.108 \pm 0.742$ \\
\hline & Osilinus lineatus & 1997 & her & 1 & Upper & 5 & $0.261 \pm 0.041$ \\
\hline & Patella vulgata & 1997 & her & 1 & Intermediate & 5 & $5.215 \pm 1.897$ \\
\hline & Cerastoderma edule & 1997 & sus & 1 & Intermediate & 5 & $0.460 \pm 0.163$ \\
\hline & Chlamys varia & 1997 & sus & 2 & Lower & 5 & $11.805 \pm 3.250$ \\
\hline & Crassostrea gigas & 1997 & sus & 3 & Lower & 5 & $1.474 \pm 0.617$ \\
\hline & Macoma balthica & 1997 & sdf & 1 & Intermediate & 3 & $0.101 \pm 0.004$ \\
\hline & Modiolus barbatus & 1997 & sus & 2 & Lower & 3 & $8.275 \pm 2.439$ \\
\hline & Mytilus edulis & 1997 & sus & 1 & Lower & 5 & $2.520 \pm 0.124$ \\
\hline & Mytilus galloprovincialis & 1997 & sus & 2 & Intermediate & 3 & $2.633 \pm 1.063$ \\
\hline & Ostrea edulis & 1998 & sus & 1 & Lower & 3 & $2.531 \pm 0.245$ \\
\hline & Scrobicularia plana & 1998 & sdf & 1 & Intermediate & 3 & $0.385 \pm 0.112$ \\
\hline & Tapes decussatus & 1997 & sus & 3 & Intermediate & 5 & $0.471 \pm 0.173$ \\
\hline & Tapes philippinarum & 1997 & sus & 3 & Intermediate & 2 & $0.329 \pm 0.001$ \\
\hline \multirow[t]{14}{*}{ Crustacea } & Balanus perforatus & 1998 & sus & 3 & Lower & 3 & $2.394 \pm 0.177$ \\
\hline & Carcinus maenas & 1997 & car & 3 & Lower & 5 & $0.297 \pm 0.086$ \\
\hline & Chtamalus stellatus & 1998 & sus & 3 & Upper & 3 & $0.062 \pm 0.007$ \\
\hline & Clibanarius erythropus & 1997 & omn & 4 & Lower & 5 & $0.619 \pm 0.484$ \\
\hline & Elminius modestus & 1998 & sus & 3 & Intermediate & 5 & $0.100 \pm 0.030$ \\
\hline & Galathea squamifera & 1998 & sus & 2 & Lower & 3 & $0.568 \pm 0.089$ \\
\hline & Hemigrapsus penicillatus & 1998 & car & 3 & Intermediate & 3 & $0.066 \pm 0.007$ \\
\hline & Necora puber & 1997 & car & 3 & Lower & 7 & $0.248 \pm 0.039$ \\
\hline & Orchestia gammarellus & 1997 & det & 4 & Upper & 3 & $0.309 \pm 0.085$ \\
\hline & Pachygrapsus marmoratus & 1997 & car & 3 & Intermediate & 3 & $0.041 \pm 0.011$ \\
\hline & Palaemon elegans & 1997 & omn & 4 & Intermediate & 3 & $0.018 \pm 0.001$ \\
\hline & Pilumnus hirtellus & 1997 & car & 3 & Lower & 5 & $0.419 \pm 0.165$ \\
\hline & Porcellana platycheles & 1997 & sus & 2 & Lower & 5 & $0.145 \pm 0.049$ \\
\hline & Xantho pillipes & 1998 & her & 4 & Lower & 3 & $0.210 \pm 0.082$ \\
\hline \multirow[t]{2}{*}{ Echinodermata } & Asterina gibbosa & 1998 & omn & 4 & Intermediate & 3 & $1.846 \pm 0.213$ \\
\hline & Psammechinus miliaris & 1997 & omn & 4 & Lower & 3 & $0.291 \pm 0.254$ \\
\hline Urochordata & Dendrodoa grossularia & 1998 & sus & 2 & Lower & 3 & $0.403 \pm 0.021$ \\
\hline \multirow[t]{2}{*}{ Teleostei } & Anguilla anguilla & 1997 & car & 4 & Intermediate & 3 & $0.082 \pm 0.037$ \\
\hline & Gobius paganellus & 1997 & car & 4 & Intermediate & 3 & $0.021 \pm 0.005$ \\
\hline
\end{tabular}

analysis. After thawing, only molluscs were de-shelled and their soft tissues were analysed. All other species were analysed in total except for Zostera noltii, in which leaves and rhizomes (+roots) were analysed separately and halophytes (Atriplex portulacoides and Sarcocornia perennis), in which only aboveground parts (leaves + stems) were analysed. Replicates (3 or 5) containing 1 or several adult individuals (depending on the average size of the species) of the same size were analysed to estimate a mean $\mathrm{Cd}$ and standard deviation. Tissues were dried for several days at $80^{\circ} \mathrm{C}$ to a constant weight and then homogenised. Three aliquots (approximately $300 \mathrm{mg}$ per aliquot) of each homogenised and dried tissues were digested in a solution of $4 \mathrm{ml}$ of $65 \% \mathrm{HNO}_{3}$ and $1 \mathrm{ml}$ of $70 \% \mathrm{HClO}_{4}$ at $80^{\circ} \mathrm{C}$ until the solution became clear. After evaporation, the residues were re-dissolved into $10 \mathrm{ml} 0.3 \mathrm{~N}$ $\mathrm{HNO}_{3}$. Cd was determined by flame or graphite furnace atomic absorption spectrophotometry (FAAS or
GF-AAS) with a deuterium background correction. Two reference tissues, dogfish liver DOLT-2 (NRCC) and the MA-A2 fish tissue standard (IAEA), were treated and analysed in the same way as the other tissues. The results for the standard reference materials were in good agreement with the certified values reported. The detection limit for Cd was $0.005 \mathrm{\mu g} \mathrm{g}^{-1}$ dry wt.

Estimation of the biomasses by stratified random sampling. Of the 63 species considered in this study, only the biomasses of some mollusc species were previously known: Pacific oysters Crassostrea gigas and European mussels Mytilus edulis from cultivated stocks estimates (P. Goulletquer, O. Le Moine pers. comm.). Biomass estimates of other species (Cerastoderma edule, Chlamys varia, Hydrobia ulvae, Macoma balthica, Crepidula fornicata, Nassarius reticulatus, Srobicularia plana, Tapes decussatus and Littorina littorea) were taken from an earlier estimate 
of stocks of non-cultivated species present on softbottom sediments of the bay (Sauriau 1987, Sauriau et al. 1989, 1998).

Estimates for the stocks of non-cultivated species on rocky substrates and for plant groups, eelgrasses and halophytes, present along the shoreline, were made specifically for the present study. The sampling protocol was based on a stratified sampling strategy (Cochran 1977) with specific strata definition, estimates of their area, random sampling in a minimum of 2 stations per strata, and then sampling by unit surface area (details are given below). The calculations of variance used the formulas for a stratified random protocol (Cochran 1977).

Biomass assessment of intertidal animal species on hard substrates: Hard substrates in the MarennesOléron Bay are mostly the low walls present in the oyster bed cultivation zones (Goulletquer \& Héral 1997, Pigeot 2001). Six strata were defined by the tidal level of the oyster cultivation zones and linked to the tidal coefficient $(<30,30-40,40-60,60-80$, $80-100,>100)$. Tidal coefficients range from 20 to 120 according to SHOM (Service Hydrographique de la Marine, Brest), 20 and 120 being related to extreme neap tide levels and extreme spring tide levels, respectively. Each stratum contained between 2 and 5 randomly selected sampling stations. Within each station, 2 linear meters of low wall were sampled. All the motile and attached epiflora and epifauna, as well as those located in the immediate surroundings (at a distance of $20 \mathrm{~cm}$ maximum on either side of the section of the wall being sampled), were collected. The organisms collected from each sampling station were sorted by species in the laboratory, and the biomass of each species was evaluated. This protocol was used in 4 sectors of the oyster cultivation zone: Château d'Oléron, Daire, Saint Trojan and Ronce-les-Bains (Fig. 2). Finally, the shellfishery exploitation registry 'Cadastre ostréicole des Affaires Maritimes Marennes' was used to make estimates of the total length of these low walls for each bathymetric stratum and for each of the 4 sectors, using the Arcview GIS softwave, release 3.2 .

Biomass assessment of intertidal plants on softbottom substrates: The biomasses of the shore halophytes (Atriplex portulacoides and Sarcocornia perennis) were evaluated on 3 geographic strata (La Perrotine, Gatseau and Brouage, Fig. 2). On each strata, 3 samples of $0.25 \mathrm{~m}^{2}$ each were made and the 2 dominant species Atriplex portulacoides $(80 \%$ of the total surface) and Sarcocornia perennis (20\%) were sampled. In the laboratory, the plants were weighed after the mud was removed. The ratio of the dry to wet weight was measured to establish a value for the dry biomass per unit surface area of each plant species.
The surface occupied by the halophytes was determined using aerial pictures with a scale of 1:25000.

For the eelgrass, Zostera noltii, living on the upper part of the shore, we evaluated the covered surface in the same way as the shore halophytes but used a SPOT satellite image obtained in September 1986 (Guillaumont 1991). The biomass was evaluated in 6 geographic strata (La Perrotine, Bellevue, Lilon, Les Doux, Le Château and Saint Trojan, Fig. 2) in which 6 quadrants, of $0.25 \mathrm{~m}^{2}$ each, were randomly sampled. In each quadrant, all the $Z$. noltii plants were collected. In the laboratory, the plants were washed, weighed wet, dried in an oven for $48 \mathrm{~h}$ and then reweighed (dry weight).

Estimation of cadmium partitioned in organisms and associated with annual biological production: The quantities of cadmium partitioned ( $Q$ in $g$ ) into the population of a given species, were evaluated in the following manner:

$$
Q=[\mathrm{Cd}] \times \mathrm{DB} \times 10^{-6}
$$

where [Cd] (in $\mu \mathrm{g} \mathrm{g}^{-1}$ of dry weight) is the concentration of cadmium and DB (in $\mathrm{g}$ ) is the dry biomass of a given species for the entire bay.

The variance estimate of $Q$ was evaluated following a formula for 2 independent random variables (Seber 1982) as:

$$
\begin{aligned}
V([\mathrm{Cd}] \times \mathrm{DB})= & V([\mathrm{Cd}]) \times V(\mathrm{DB})+(E([\mathrm{Cd}]))^{2} \times V(\mathrm{DB}) \\
& +V([\mathrm{Cd}]) \times(E(\mathrm{DB}))^{2}
\end{aligned}
$$

where $E([\mathrm{Cd}])$ and $E(\mathrm{DB})$ are the mean values of cadmium concentration and dry weight biomass for a given species for the entire bay, respectively.

Evaluation of the quantity of cadmium associated with the annual production of living matter for the population of a given species ( $F$ in $\mathrm{g} \mathrm{yr}^{-1}$ ) was estimated as follows:

$$
F=Q \times P / B
$$

where $Q$ is the quantity of $\mathrm{Cd}$ partitioned into the population of a given species and $P / B$ is the productivity (the production $P$ of a given species divided by its wet biomass $B$ at a given instant). $P / B$ data were taken from the literature (e.g. Leguerrier et al. 2003 and references therein).

\section{RESULTS AND DISCUSSION}

\section{Cadmium concentrations in sampled species}

The median of the measured Cd concentrations in the organisms was $0.4 \mu \mathrm{g} \mathrm{g}^{-1}$ dry wt for the 63 species from the Marennes-Oléron Bay. The concentrations of cadmium in the different benthic and suprabenthic 
Table 2. Dry biomass (mean $\pm \mathrm{SD}$ in $\mathrm{t}$ ) of the principal intertidal taxa and species of the Marennes-Oléron Bay ranked in decreasing order. Reference sources (Ref.): 1, P. Goulletquer \& O. Le Moine (pers. comm.); 2, Sauriau (1987); 3, this study

\begin{tabular}{|c|c|c|c|c|c|}
\hline Species & Dry biomass & Ref. & Species & Dry biomass & Ref. \\
\hline Microphytobenthos & $1918.0 \pm 383.0$ & 3 & Modiolus barbatus & $0.4 \pm 0.1$ & 3 \\
\hline Crassostrea gigas & & & Chlamys varia & $0.4 \pm 0.1$ & 3 \\
\hline Natural and cultivated & $1835.2 \pm 428.8$ & 1 & Clibanarius erythropus & $0.3 \pm 0.1$ & 3 \\
\hline Atriplex portulacoides & & & Pilumnus hirtellus & $0.3 \pm 0.1$ & 3 \\
\hline Leaves \& stem & $1022.5 \pm 200.0$ & 3 & Patella vulgata & $0.3 \pm 0.1$ & 3 \\
\hline Zostera noltii & & & Gibbula umbilicalis & $0.2 \pm 0.1$ & 3 \\
\hline Leaves & $279.0 \pm 70.0$ & 3 & Ulva lactuca & $0.2 \pm 0.1$ & 3 \\
\hline Rhizomes \& roots & $306.0 \pm 96.0$ & 3 & Galathea squamifera & $0.1 \pm 0.1$ & 3 \\
\hline Cerastoderma edule & $273.4 \pm 62.5$ & 2 & Hediste diversicolor & $0.1 \pm 0.1$ & 3 \\
\hline Sarcocornia perennis & & & Osilinus lineatus & $0.1 \pm 0.1$ & 3 \\
\hline Leaves \& stem & $209.9 \pm 40.0$ & 3 & Marphysa sanguinea & $0.1 \pm 0.1$ & 3 \\
\hline $\begin{array}{l}\text { Mytilus edulis } \\
\text { natural and cultivated }\end{array}$ & $121.4 \pm 21.2$ & 1 & Enteromorpha intestinalis & $<0.1$ & 3 \\
\hline Hydrobia ulvae & $85.1 \pm 9.2$ & 2 & $\begin{array}{l}\text { Necora puber } \\
\text { Nucella lapillus }\end{array}$ & $\begin{array}{l}<0.1 \\
<0.1\end{array}$ & $\begin{array}{l}3 \\
3\end{array}$ \\
\hline Macoma balthica & $67.6 \pm 11.2$ & 2 & Porphyra umbilicalis & $<0.1$ & 3 \\
\hline Scrobicularia plana & $45.8 \pm 15.2$ & 2 & Anguilla anguilla & $<0.1$ & 3 \\
\hline Crepidula fornicata & $29.2 \pm 8.9$ & 2 & Littorina obtusata & $<0.1$ & 3 \\
\hline Nassarius reticulatus & $27.1 \pm 10.2$ & 2 & Asterina gibbosa & $<0.1$ & 3 \\
\hline Fucus vesiculosus & $25.0 \pm 17.4$ & 3 & Lepidochiton cinereus & $<0.1$ & 3 \\
\hline Tapes decussatus & $21.7 \pm 7.6$ & 2 & Archidoris pseudoargus & $<0.1$ & 3 \\
\hline Tapes philippinarum & $10.9 \pm 2.5$ & 3 & Chtamalus stellatus & $<0.1$ & 3 \\
\hline Fucus serratus & $8.9 \pm 8.2$ & 3 & Ceramium ciliatum & $<0.1$ & 3 \\
\hline Pachygrapsus marmoratus & $5.8 \pm 1.2$ & 3 & Gobius paganellus & $<0.1$ & 3 \\
\hline Ascophyllum nodosum & $3.3 \pm 3.2$ & 3 & Dendrodoa grossularia & $<0.1$ & 3 \\
\hline Porcellana platycheles & $2.8 \pm 0.4$ & 3 & Mytilus galloprovincialis & $<0.1$ & 3 \\
\hline Ocinebrellus inornatus & $2.4 \pm 0.3$ & 3 & Ostrea edulis & $<0.1$ & 3 \\
\hline Carcinus maenas & $2.3 \pm 0.5$ & 3 & Balanus perforatus & $<0.1$ & 3 \\
\hline Halichondria bowerbanki & $1.7 \pm 1.0$ & 3 & Gibbula cineraria & $<0.1$ & 3 \\
\hline Littorina littorea & $1.4 \pm 0.8$ & 3 & Gigartina acicularis & $<0.1$ & 3 \\
\hline Nassarius incrassatus & $1.4 \pm 0.9$ & 3 & Laurencia pinnatifida & $<0.1$ & 3 \\
\hline Elminius modestus & $1.3 \pm 0.3$ & 3 & Orchestra gammarellus & $<0.1$ & 3 \\
\hline Xantho pillipes & $0.7 \pm 0.2$ & 3 & Palaemon elegans & $<0.1$ & 3 \\
\hline Hemigrapsus penicillatus & $0.6 \pm 0.2$ & 3 & Psammechinus miliaris & $<0.1$ & 3 \\
\hline Ocenebra erinacea & $0.4 \pm 0.1$ & 3 & Actinia equina & $<0.1$ & 3 \\
\hline Anemonia viridis & $0.4 \pm 0.1$ & 3 & Gracilaria verrucosa & $<0.1$ & 3 \\
\hline
\end{tabular}

organisms at the Château d'Oléron station in the spring seasons of 1997, 1998 and 1999 were distinguished by 3 main groups (Table 1). The majority of benthic and suprabenthic organisms had relatively low concentrations, that is, less then $1 \mu \mathrm{g} \mathrm{g}^{-1}$ dry wt. Eleven species had concentrations between 1 and $3 \mu \mathrm{g} \mathrm{g}^{-1}$ dry wt. For primary producers, there were microphytobenthos and 2 macrophytes (Ceramium ciliatum, Zostera noltii). For animal species there were 3 gastropods (Archidoris pseudoargus, Littorina littorea and L. btusata), 4 bivalves (Crassostrea gigas, Mytilus edulis, M. galloprovincialis and Ostrea edulis), 1 crustacean (Balanus perforatus) and 1 echinoderm (Asterina gibbosa). Six gastropods (Nassarius incrassatus, N. reticulatus, Nucella lapillus, Ocenebra erinacea, Ocinebrellus inornatus and Patella vulgata) and 2 bivalves (Chlamys varia and Modiolus barbatus) had concentrations higher than $5 \mu \mathrm{g} \mathrm{g}^{-1}$ dry wt, and up to $10 \mu \mathrm{g} \mathrm{g}^{-1}$ dry wt.

\section{Estimation of the biomass of intertidal species}

The total dry biomass for the 63 benthic and suprabenthic organisms of the Marennes-Oléron Bay was about 8800 t (Table 2). Six species (the 2 cultivated bivalves Crassostrea gigas and Mytilus edulis, the shore halophytes Atriplex portulacoïdes and Sarcocornia perennis, the dwarf eelgrass Zostera noltii, and the cockle Cerastoderma edule) plus the microphytobenthos represented more than $96 \%$ of the total dry biomass; each has a dry biomass (DB) greater than $100 \mathrm{t}$. Eight other species, which are all found on sandy-mud substrates, with the exception of 1 brown algae (Fucus serratus), had DB values between 10 and 100 t. These 14 species, plus microphytobenthos, amounted to $8771 \mathrm{t}$ of dry material, or more than $99.5 \%$ of the total DB. The remaining $0.5 \%$ of the total dry biomass constituted 10 species living on rocky substrates and the remaining 39 species sampled had DB values lower than $1 \mathrm{t}$ each. 
Table 3. Quantities of cadmium fixed $(Q \pm \mathrm{SD}$ in $\mathrm{g})$ by the principal intertidal taxa and species of the Marennes-Oléron Bay, ranked in decreasing order

\begin{tabular}{|c|c|c|c|}
\hline Species & Cd fixed (g) & Species & Cd fixed $(g)$ \\
\hline Crassostrea gigas & & Pachygrapsus marmoratus & $0.2 \pm 0.1$ \\
\hline Natural and cultivated & $2705.1 \pm 1108.0$ & Clibanarius erythropus & $0.2 \pm 0.2$ \\
\hline Microphytobenthos & $2343.8 \pm 383.0$ & Xantho pillipes & $0.1 \pm 0.1$ \\
\hline Zostera noltii & $565.6 \pm 256.7$ & Pilumnus hirtellus & $0.1 \pm 0.1$ \\
\hline Leaves & $189.2 \pm 141.0$ & Elminius modestus & $0.1 \pm 0.1$ \\
\hline Rhizomes \& roots & $376.4 \pm 214.0$ & Archidoris pseudoargus & $0.1 \pm 0.1$ \\
\hline Mytilus edulis & & Asterina gibbosa & $0.1 \pm 0.1$ \\
\hline Natural and cultivated & $305.9 \pm 54.6$ & Gibbula umbilicalis & $0.1 \pm 0.1$ \\
\hline Nassarius reticulatus & $141.3 \pm 80.4$ & Galathea squamifera & $0.1 \pm 0.1$ \\
\hline Cerastoderma edule & $125.8 \pm 54.0$ & Littorina obtusata & $<0.1$ \\
\hline Atriplex portulacoides & & Psammechinus miliaris & $<0.1$ \\
\hline Leaves \& stem & $101.2 \pm 59.6$ & Hemigrapsus penicillatus & $<0.1$ \\
\hline Crepidula fornicata & $22.2 \pm 11.8$ & Ostrea edulis & $<0.1$ \\
\hline Scrobicularia plana & $17.6 \pm 8.0$ & Balanus perforatus & $<0.1$ \\
\hline Ocinebrellus inornatus & $14.9 \pm 2.6$ & Anguilla anguilla & $<0.1$ \\
\hline Tapes decussatus & $10.2 \pm 5.4$ & Osilinus lineatus & $<0.1$ \\
\hline Nassarius incrassatus & $7.3 \pm 4.6$ & Necora puber & $<0.1$ \\
\hline Macoma balthica & $6.8 \pm 1.2$ & Mytilus galloprovincialis & $<0.1$ \\
\hline Fucus serratus & $5.0 \pm 4.8$ & Lepidochiton cinereus & $<0.1$ \\
\hline Macoma balthica & $6.8 \pm 1.2$ & Ceramium ciliatum & $<0.1$ \\
\hline Chlamys varia & $4.4 \pm 1.5$ & Marphysa sanguinea & $<0.1$ \\
\hline Hydrobia ulvae & $4.1 \pm 0.6$ & Anemonia viridis & $<0.1$ \\
\hline Tapes philippinarum & $3.6 \pm 2.5$ & Dendrodoa grossularia & $<0.1$ \\
\hline Modiolus barbatus & $3.0 \pm 1.2$ & Gibbula cineraria & $<0.1$ \\
\hline Sarcocornia perennis & & Enteromorpha intestinalis & $<0.1$ \\
\hline Leaves \& stem & $2.7 \pm 0.7$ & Porphyra umbilicalis & $<0.1$ \\
\hline Ocenebra erinacea & $2.5 \pm 0.7$ & Tapes decussatus & $<0.1$ \\
\hline Littorina littorea & $1.7 \pm 1.0$ & Gigartina acicularis & $<0.1$ \\
\hline Fucus vesiculosus & $1.4 \pm 1.1$ & Orchestra gammarellus & $<0.1$ \\
\hline Patella vulgata & $1.4 \pm 0.6$ & Gobius paganellus & $<0.1$ \\
\hline Carcinus maenas & $0.7 \pm 0.3$ & Palaemon elegans & $<0.1$ \\
\hline Nucella lapillus & $0.6 \pm 0.3$ & Chtamalus stellatus & $<0.1$ \\
\hline Porcellana platycheles & $0.4 \pm 0.1$ & Actinia equina & $<0.1$ \\
\hline Halichondria bowerbanki & $0.4 \pm 0.3$ & Laurencia pinnatifida & $<0.1$ \\
\hline Ascophyllum nodosum & $0.4 \pm 0.4$ & Ulva lactuca & $<0.1$ \\
\hline
\end{tabular}

\section{Quantities of cadmium in the phytobenthos and zoobenthos}

The quantity of cadmium in the biomass of the 63 principal benthic, suprabenthic and intertidal species, as well as in the microphytobenthos of the MarennesOléron Bay was $6.3 \mathrm{~kg}$ with a standard deviation of $1.2 \mathrm{~kg}$ (Table 3). Ninety-eight percent of this cadmium was within 6 species, plus the microphytobenthos, and all of them contained quantities of cadmium higher than $0.1 \mathrm{~kg}$. These species were the 2 cultivated bivalve species (Crassostrea gigas and Mytilus edulis), the dwarf eelgrass Zostera noltii, the cockle Cerastoderma edule, 1 of the 2 principal shore halophytes (Atriplex portulacoïdes) and the reticulated dog whelk (Nassarius reticulatus). If we add the quantity of cadmium in the 7 taxa above to that accumulated by the following 5: Crepidula fornicata, Ocinebrellus inornatus, Scrobicularia plana, Tapes decussatus and Patella vulgata (all of which have biomass accumulations between 0.1 and $0.01 \mathrm{~kg}$ of $\mathrm{Cd}$ ), then these species account for over $99 \%$ of the cadmium partitioned into the benthic biomass. Thus, 11 benthic species plus the microphytobenthos alone accounted for the majority of the cadmium.

\section{Species contamination}

The initial data available from the RNO on the quality of the marine environment demonstrated that there are chronic levels of cadmium pollution in the Marennes-Oléron Bay (RNO 1988, 1995, 2000). Oysters collected from this bay contained $\mathrm{Cd}$ concentrations systematically higher than those generally measured in oysters sampled from other French coastal regions: the measured values have shown a tendency to decrease since 1985, and have returned to concentrations below $5 \mathrm{\mu g} \mathrm{g}^{-1}$ dry wt since the mid-1990s (RNO 2000, 2004). The maximum allowable $\mathrm{Cd}$ in 
bivalves is $1 \mathrm{\mu g} \mathrm{g}^{-1}$ wet wt (European Community regulation CEE/466/2001 on 8 March 2001, applicable 5 April 2002) above which the consumption and commercialisation of shellfish is forbidden. Thus, using a ratio of wet to dry wt of near 5, some other species analysed from the bay (scallops, mussels, limpets, dog whelks) also exceeded the maximum allowable $\mathrm{Cd}$ in bivalves. The majority (71\%) of the species analysed, notably the fish, crustacean and echinoderm species most likely to be consumed by humans, had Cd concentrations below $1 \mu \mathrm{gg} \mathrm{g}^{-1}$ dry wt (Table 1). These results are in the same range as concentrations measured in these taxa in other industrialised coastal zones (Bryan 1984).

Nineteen species in the Marennes-Oléron Bay had $\mathrm{Cd}$ concentrations higher than $1 \mu \mathrm{g} \mathrm{g}^{-1}$ dry wt. Among these, only 4 species, or groups of species, were not molluscs: the red algae Ceramium ciliatum, the starfish Asterina gibbosa, the barnacle Balanus perforatus, which had a concentration among the lowest measured for barnacles collected from Cd contaminated zones (Phillips \& Rainbow 1988), and the microphytobenthos. To the best of our knowledge, this is the first time that $\mathrm{Cd}$ analyses have been made on the microphytobenthos of the Marennes-Oléron Bay, a biological compartment that is very abundant on all bare mudflats of this bay (Guarini et al. 1998, Blanchard et al. 2000). This microphytobenthos had a Cd concentra-

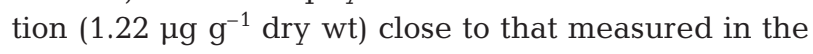
planktonic diatoms collected from the Seine Bay (which is also subjected to chronic Cd pollution) and of planktonic diatoms collected in the Marennes-Oléron Bay (Miramand et al. 1993, 2001a).

The mollusc species with $\mathrm{Cd}$ concentrations higher than $1 \mu \mathrm{g} \mathrm{g}^{-1}$ dry wt included neogastropods (Nassarius incrassatus, N. reticulatus, Nucella lapillus, Ocenebra erinacea, Ocinebrellus inornatus), filibranch bivalves (Chlamys varia, Crassostrea gigas, Modiolus barbatus, Mytilus edulis, M. galloprovincialis, Ostrea edulis), the nudibranch Archidoris pseudoargus, 2 littorina species (Littorina littorea and L. obtusata) and the limpet Patella vulgata. Most of these species are known to bioaccumulate Cd (Bryan 1984, Phillips 1977, Langston \& Zhou 1987). Among the molluscs, the bioaccumulation of cadmium does not seem to be linked to their taxonomic group, nor even trophic behaviour (Table 1). For example, among the archeogastropods, Patella vulgata had Cd concentrations an order of magnitude higher than Gibbula umbilicalis (Kruskal-Wallis rank test, $\mathrm{p}<0.03$, see Table 1 Gastropoda section). The concentration of Cd measured for species belonging to the same taxa is not linked to their trophic level within the benthic food web and we observe large differences in the concentrations measured for species with the same feeding behaviour. This is, for instance, most apparent for grazers and for the filter feeders including facultative suspension-feeders. Within bivalves, a clear split appears between the filibranchs (Mytilus galloprovincialis, M. edulis, Modiolus barbatus, Crassostrea gigas, Chlamys varia with significant differences between species, Kruskal-Wallis rank test $\mathrm{p}<0.01$, which had systematically greater concentrations than the median) and the eulamellibranchs (Cerastoderma edule, Tapes decussatus, T. philippinarum, Macoma balthica, Scrobicularia plana with no significant differences between species, Kruskal-Wallis rank test $\mathrm{p}>0.05$, and all with low concentrations, near the median) since highly significant differences occurred between the 2 groups (Kruskal-Wallis rank test, $\mathrm{p}<0.001$, see Table 1 Bivalvia section). Thus, it seems unreasonable to group all the bivalves together or to separate trophic groups among bivalves on the basis of their bioaccumulation of cadmium.

\section{Contamination at the ecosystem level}

The quantity of Cd partitioned into the principal benthic species of the bay appears variable within 7 main species. The largest fraction are the intertidal species, which account for about $6.4 \mathrm{~kg}$ of $\mathrm{Cd}$ (Table 3). Studies of subtidal species stocks in the Marennes-Oléron Bay (Sauriau 1987 and renewed for Crepidula fornicata by Sauriau et al. 1998) estimated that approximately $0.5 \mathrm{~kg}$ of cadmium was partitioned into subtidal fauna (Table 4). Thus, a total of $7 \mathrm{~kg}$ of Cd may be contained in all benthic species living in the bay. At the ecosystem level, only a few species or groups of species seem to be relevant for the partitioning of $\mathrm{Cd}$ (Fig. 3). These are essentially the Pacific oysters Crassostrea gigas and the microphytobenthos, each representing about $40 \%$ of the total. Five other species also play an important role in Cd partitioning: eelgrass Zostera noltii at $9 \%$, mussels Mytilus edulis at $5 \%$, dog whelks Nassarius reticulatus, cockles Cerastoderma edule and halophytes Atriplex portulacoides at $2 \%$ each. In conclusion, there are 6 spe-

Table 4. Quantities of cadmium fixed $(Q \pm \mathrm{SD}$ in $\mathrm{g})$ by the principal benthic subtidal species in the Marennes-Oléron Bay, ranked in decreasing order. DB: dry biomass (t) for each species; [Cd]: concentration of cadmium

\begin{tabular}{|lccc|}
\hline Species & $\begin{array}{c}\mathrm{DB} \\
(\mathrm{t})\end{array}$ & $\begin{array}{c}{[\mathrm{Cd}]} \\
\left(\mu \mathrm{g} \mathrm{g}^{-1} \mathrm{DB}\right)\end{array}$ & $\begin{array}{c}Q \\
(\mathrm{~g} \text { of Cd})\end{array}$ \\
\hline Chlamys varia & $15.6 \pm 7.9$ & $11.8 \pm 3.2$ & $184.1 \pm 105.0$ \\
Nassarius reticulatus & $28.7 \pm 5.3$ & $5.2 \pm 2.1$ & $149.2 \pm 66.3$ \\
Mytilus edulis & $33.5 \pm 18.9$ & $2.5 \pm 0.1$ & $83.7 \pm 47.4$ \\
Crepidula fornicata & $49.2 \pm 28.6$ & $0.7 \pm 0.3$ & $34.4 \pm 24.9$ \\
\hline
\end{tabular}




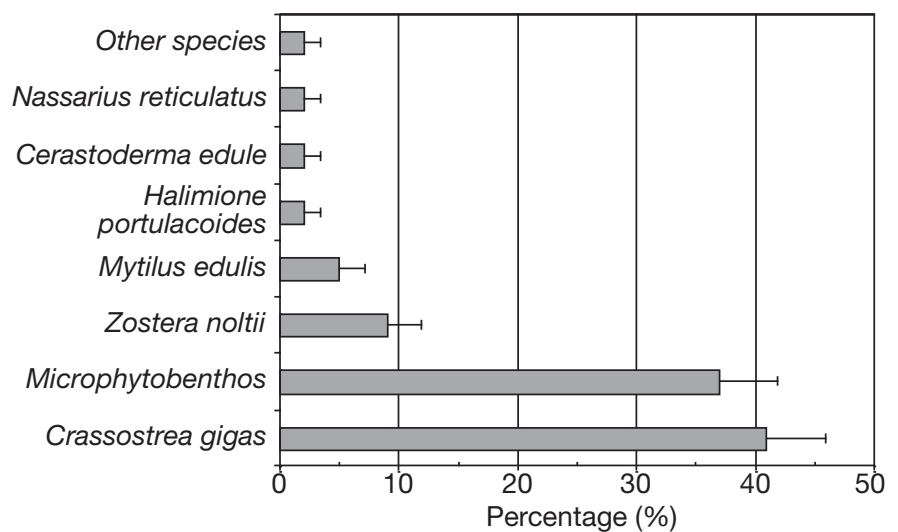

Fig. 3. Percentages of $\mathrm{Cd}$ partitioned among the benthic species in the Marennes-Oléron Bay

cies and 1 group of species (microphytobenthos) which contain up to $98 \%$ of the $\mathrm{Cd}$ present in the benthic species of the Marennes-Oléron Bay. At the ecosystem level, all the other benthic species are considered negligible for the partitioning of $\mathrm{Cd}$. Individually, each of them represents less than $0.1 \%$ of the total Cd partitioned into the organisms of the benthic ecosystem.

\section{Transfers within the trophic foodweb}

For the Marennes-Oléron Bay, almost all the partitioned Cd (97\%) is associated with only 2 trophic levels: the primary producers ( $3 \mathrm{~kg}$ of $\mathrm{Cd}$ ) and the filter feeders (3.2 kg of Cd) (Fig. 4, Table 3). By comparison, the quantities of Cd partitioned by the other trophic levels appear negligible. In particular, the $\mathrm{Cd}$ mass partitioned into the carnivores $(<0.2 \mathrm{~kg})$ was small, and most (84\%) of this cadmium was associated with the reticulated dog whelk Nassarius reticulatus. Based on this observation, there is a clear absence of biomagnification of $\mathrm{Cd}$ in the trophic network at the ecosystem level. This has also been observed in numerous other studies, which consider the biomagnification of this metal at the species level only (Bryan 1984). Yet, in the present study, a biomagnification of $\mathrm{Cd}$ was described for short food chains with just 2 trophic levels, for example between the microphytobenthos and the suspension feeders.

The quantities of $\mathrm{Cd}$ associated with the annual production of biomass for the principal benthic and suprabenthic intertidal species of the Marennes-Oléron Bay have been estimated (Table 5). These estimates are considered to represent the uptake of $\mathrm{Cd}$ in the ecosystem during biological production and thus, the quantities of $\mathrm{Cd}$ which are potentially available to be transferred within the trophic network. The intertidal mudflats of the MarennesOléron Bay are central to an intense microphytobenthic primary production where the sedimentary chlorophyll levels are frequently higher than $100 \mathrm{mg} \mathrm{chl} \mathrm{a} \mathrm{\textrm {m } ^ { - 2 }}$ (Guarini et al. 1998) and the net production (actual production less the losses caused by suspension, grazing, etc.) has been measured at $1 \mathrm{~g} \mathrm{C} \mathrm{m}^{-2} \mathrm{~d}^{-1}$ (Blanchard et al. 1998), resulting in an annual production of $300 \mathrm{~g} \mathrm{C}$ $\mathrm{m}^{-2} \mathrm{yr}^{-1}$. This intense production explains the central role occupied by the microphytobenthos in the trophic network of the intertidal areas of the Marennes-Oléron Bay (Leguerrier et al. 2003). The microphytobenthos is

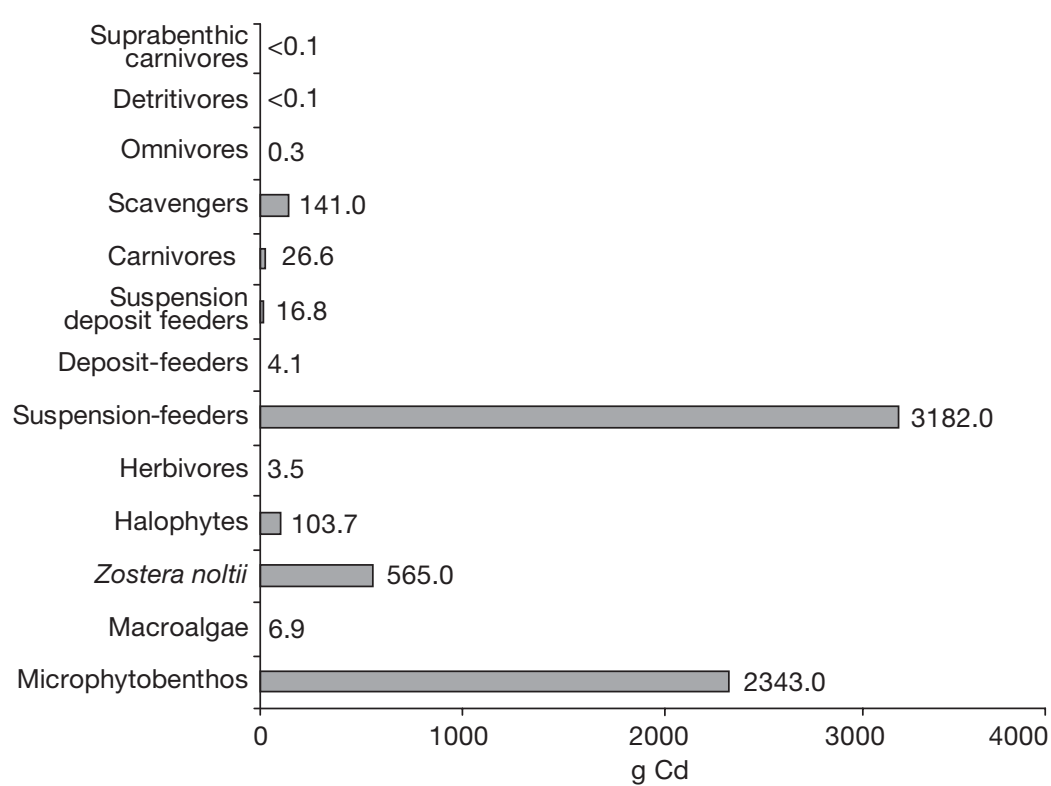

Fig. 4. Cd masses (g) estimated for the major benthic trophic groups within the Marennes-Oléron Bay

Table 5. Estimated quantities of cadmium associated with the annual biomass production $(P / B)$ of the principal benthic species in different zones of the Marennes-Oléron Bay

\begin{tabular}{|c|c|c|c|c|}
\hline Zone & $\begin{array}{c}\text { Surface } \\
\left(\mathrm{km}^{2}\right)\end{array}$ & Principal species & $\begin{array}{c}P / B \\
\left(\mathrm{yr}^{-1}\right)\end{array}$ & $\begin{array}{c}\mathrm{Cd} \\
\left(\mathrm{kg} \mathrm{yr}^{-1}\right)\end{array}$ \\
\hline Shellfishery areas & 30.00 & $\begin{array}{l}\text { Crassostrea gigas, } \\
\text { Mytilus edulis, Fucus } \\
\text { serratus, Ocenebra } \\
\text { erinacea, Patella vulgata }\end{array}$ & 0.33 & 1.4 .00 \\
\hline Bare mudflats & 96.00 & Microphytobenthos & 80.00 & 188.00 \\
\hline Seagrass meadows & 8.65 & Zostera noltii & 3.40 & 1.90 \\
\hline Upper shore & 1.20 & $\begin{array}{l}\text { Atriplex portulacoïdes, } \\
\text { Sarcocornia perennis }\end{array}$ & 0.60 & $<0.10$ \\
\hline
\end{tabular}


the most important source of food for the majority of deposit feeder species which also make up the largest portion of the intertidal benthic population in the Marennes-Oléron Bay (Riera et al. 1996). The estimate for the quantities of Cd associated with the annual production in the microphytobenthic compartment (approximately $188 \mathrm{~kg} \mathrm{yr}^{-1}$ [200 $\mathrm{ng}$ of $\mathrm{Cd} \mathrm{cm}^{-2} \mathrm{yr}^{-1}$ ]) exceeded the other benthic compartments by 2 orders of magnitude (Table 5). Stable isotope tracer studies have shown that microphytobenthos are a trophic resource available to the commercially exploited suspension feeders in the bay, such as oysters, mussels and cockles (Riera et al. 1996, Sauriau \& Kang 2000). Therefore, the role of microphytobenthos in the cycling of $\mathrm{Cd}$ in mudflat zones should be taken into account in future biogeochemical models in order to determine how the microphytobenthic compartment participates in $\mathrm{Cd}$ transfer processes to suspension and deposit feeders.

Humans are the most important consumers of shellfish sourced from the bay, and thus Cd contamination of oysters represents a potentially non-negligible source of contamination of human consumers by $\mathrm{Cd}$. The quantity of $\mathrm{Cd}$ associated with the biomass production of suspension feeders was approximately $1.4 \mathrm{~kg} \mathrm{yr}^{-1}$, which is relatively low. However, Cd associated with the oysters represented the major portion of this pool (64\%). In order to exceed the weekly tolerable dosage (WTD) of Cd in humans, recommended by the JECFA (7 $\mathrm{ug} \mathrm{kg}^{-1}$ bodyweight, Joint Expert Committee for Food Additives, FAO-WHO), it would be necessary to consume, on average, almost $3.6 \mathrm{~kg}$ of oysters per week (Miramand et al. 2001b). This quantity is higher than that known to be consumed, even by the large consumers of shellfish from the Charente-Maritime region, who consume up to $38.5 \mathrm{~kg} \mathrm{yr}^{-1}$, of which only $24.8 \mathrm{~kg}$ correspond to oysters (Anonymous 1994).

The eelgrass meadows are a possible vector of $\mathrm{Cd}$ to some migratory bird populations. Marennes-Oléron Bay is an overwintering location for a large population of Brent geese Branta bernicla, a bird that specialises in grazing on eelgrass (Charman 1979). The Cd associated with the eelgrass meadows was estimated at more than $2 \mathrm{~kg} \mathrm{yr}^{-1}$ (Table 5), which when divided by the surface area of all the eelgrass meadows in the bay represented $23 \mathrm{ng}$ of $\mathrm{Cd} \mathrm{cm}^{-2} \mathrm{yr}^{-1}$. This result is consistent with estimates of Wassermann et al. (1991) from Arcachon Bay, France. Considering a daily consumption of $100 \mathrm{~g}$ of eelgrass per bird, this represents a weekly consumption of approximately $63 \mu \mathrm{g}$ of $\mathrm{Cd}$, which when calculated relative to the average weight of a Brent goose $(2 \mathrm{~kg})$ is almost 20 times higher than the WTD recommended for $\mathrm{Cd}$ in humans. However, $\mathrm{Cd}$ accumulation has not yet been studied in these birds, or the other overwintering wading birds, which may represent a potential pathway to export Cd out of the bay.

\section{Ecosystem-wide budget of $\mathrm{Cd}$ in the Marennes-Oléron Bay}

Using the quantities of Cd partitioned by the different benthic species and communities of the MarennesOléron Bay (Tables 4 \& 5), an ecosystem-wide budget of the quantities of $\mathrm{Cd}$ present in each of the biological and physical compartments in the bay has been estimated (Table 6).

One compartment, the nekton, has not been studied yet. The quantities of $\mathrm{Cd}$ partitioned by fish and cephalopods living in the Marennes-Oléron Bay remain unclear because of their seasonal migrations. In the Marennes-Oléron Bay, mullet Liza ramada and cuttlefish Sepia officinalis represent the majority of the nektonic biomass in the bay. Using an average Cd concentration of $0.02 \mu \mathrm{g} \mathrm{g}^{-1}$ dry wt (measured in several species, Pigeot 2001) and a maximum biomass of $10000 \mathrm{t}$, the quantity of Cd partitioned by fish may be estimated at approximately $40 \mathrm{~g}$, which can be considered negligible relative to the other compartments. The amount of $\mathrm{Cd}$ parti-

Table 6. Global budget ${ }^{\mathrm{a}}$ of cadmium estimated for the Marennes-Oléron Bay

\begin{tabular}{|c|c|c|}
\hline $\begin{array}{l}\text { Primary } \\
\text { compartments }\end{array}$ & $\begin{array}{c}\text { Secondary } \\
\text { compartments }\end{array}$ & $\begin{array}{l}\text { Cd total } \\
(\mathrm{kg})\end{array}$ \\
\hline Water & $\begin{array}{c}\text { Dissolved } \\
\text { Particulate }\end{array}$ & $\begin{array}{c}13 \\
7\end{array}$ \\
\hline Pelagos & $\begin{array}{l}\text { Phytoplankton }^{\mathrm{b}} \\
\text { Zooplankton }^{\mathrm{C}} \\
\text { Nekton }\end{array}$ & $\begin{array}{l}0.2-0.4 \\
0.01-0.05 \\
\quad>0.2\end{array}$ \\
\hline Benthos & $\begin{array}{l}\text { Microphytobenthos } \\
\text { Other primary producers } \\
\text { Filter feeders } \\
\text { Other consumers }\end{array}$ & $\begin{array}{l}2.3 \\
0.7 \\
3.2 \\
0.2\end{array}$ \\
\hline Sediment ${ }^{\mathrm{d}}$ & & 1000 \\
\hline \multicolumn{3}{|c|}{$\begin{array}{l}{ }^{a} \text { Calculations used the following values from the litera- } \\
\text { ture: average volume of the basin } 574 \text { million } \mathrm{m}^{3} \text { (Soletch- } \\
\text { nik et al. 1998); average turbidity of } 100 \mathrm{mg} \mathrm{l}^{-1} \text { (Sornin et } \\
\text { al. 1986); average dissolved Cd concentration of } 20 \mathrm{ng} \mathrm{l}^{-1} \\
\text { (B. Boutier pers. comm.) and an average particulate Cd } \\
\text { concentration of } 0.26 \mathrm{\mu g} \mathrm{g}^{-1} \text { (Pigeot 2001) }\end{array}$} \\
\hline \multicolumn{3}{|c|}{$\begin{array}{l}{ }^{\text {b }} \text { Phytoplankton average springtime concentration of } 5 \mu \mathrm{g} \\
\text { chl } \mathrm{al}^{-1} \text { (Héral et al. 1984); measured concentration of Cd } \\
\text { in pelagic diatoms } 1.19 \mathrm{\mu g} \mathrm{g}^{-1} \text { dry wt (Miramand et al. } \\
\text { 2001a) }\end{array}$} \\
\hline \multicolumn{3}{|c|}{$\begin{array}{l}\text { 'Zooplankton estimated biomass of } 9.86 \mathrm{mg} \text { of } \mathrm{C} \mathrm{m}^{-3} \\
\text { (Sautour \& Castel 1998); measured Cd concentration in } \\
\text { zooplankton } 1.17 \mathrm{\mu g} \mathrm{g}^{-1} \text { dry wt (Miramand et al. 2001a) }\end{array}$} \\
\hline \multicolumn{3}{|c|}{$\begin{array}{l}\text { dSediments: sedimentation rate in the basin was } 1 \mathrm{~cm} \text { of } \\
\text { compacted mud per year (Raillard et al. 1994) even if } \\
\text { locally the sediment dynamics depend on the geomorph- } \\
\text { ology of the mudflat (Gouleau et al. 2000); mudflat sur- } \\
\text { face area of } 96 \mathrm{~km}^{2} \text { with an average mud density of } 1.4 \\
\text { (Gouleau et al. 2000); average measured Cd concentra- } \\
\text { tion of } 0.14 \mathrm{\mu g} \mathrm{g}^{-1} \text { dry wt (Gonzalez et al. 1991) }\end{array}$} \\
\hline
\end{tabular}


tioned by the cephalopods was estimated at $0.2 \mathrm{~kg}$ applying an approximate biomass of $1000 \mathrm{t}$ and an average concentration of $0.02 \mu \mathrm{g} \mathrm{Cd} \mathrm{g}^{-1}$ dry wt measured in cuttlefish collected off La Rochelle, just beyond the northern limit of the bay (Bustamante et al. 1998). A similar calculation could be done for epibentic crustaceans with an average concentration higher than $1 \mu \mathrm{g}$ $\mathrm{Cd} \mathrm{g}^{-1}$ dry wt but biomasses lower than 100 to $500 \mathrm{t}$. Thus, the total quantity of Cd partitioned by the pelagic compartments of the bay is between 0.5 and $0.6 \mathrm{~kg}$, which would be considered low at the scale of the whole bay, when compared to the water column $(20 \mathrm{~kg})$ and to the benthos (6.4 kg) (Table 6).

Overall, the largest pool of cadmium was associated with the upper $5 \mathrm{~cm}$ of sediments (equivalent to about $5 \mathrm{yr}$ of deposition) (Table 6). Cohesive sediments of Marennes-Oléron Bay intertidal areas may function as either a geochemical sink for $\mathrm{Cd}$, or as a source, through long-term tidal erosion-sedimentation cycles (Gouleau et al. 2000), biodeposition by oysters and mussels (Sornin et al. 1983, 1986) and infauna bioturbation (El Ghobary \& Dumon 1984). Gonzalez et al. (1991) have estimated that the diffusive flux of $\mathrm{Cd}$ from the sediments of the bay to the water column is, on average, $150 \mathrm{ng}$ of $\mathrm{Cd} \mathrm{cm}^{-2} \mathrm{yr}^{-1}$. Fluxes of $\mathrm{Cd}$ out of the sediments could be enhanced by the activities of benthic deposit-feeders (meiofauna: Green \& Chandler 1994 and macrofauna: Watson et al. 1993). However, spatial variability in species composition and density (Sauriau et al. 1989), predominance of upwards vs downward sediment reworking depending on specific feeding behaviour (e.g. Rasmussen et al. 2000) and the balance between stabilising effects of microphytobenthic biofilms on surface sediments vs destabilising effects by deposit-feeder reworking (Orvain et al. 2004), may add a significant degree of variability in the final estimates. In addition, cadmium trapped upstream from the bay, in the bottom sediments of the Garonne River, could be released during future dredging projects behind the numerous hydroelectric dams installed on this river, and therefore increase the flux of $\mathrm{Cd}$ to the Marennes-Oléron Bay. An integrated ecosystem study of $\mathrm{Cd}$ transport along the entire continuum, from the source (the Lot River) through the Gironde Estuary to the Marennes-Oléron Bay, seems necessary, as even small changes in $\mathrm{Cd}$ partitioning among the largest compartments may have major negative consequences to the biota and could also adversely affect the socioeconomic structures of the Marennes-Oléron Bay.

Acknowledgements. The authors are grateful to Dr P. Bustamante, G. Radenac, P. Richard and all the undergraduate students of the LBEM for assistance with sample collection in the field. Special thanks to Dr B. Boutier, A. Gérard, P. Goulletquer and 4 anonymous referees for their sound advice and reviews, to F. Rivet, E. Richard for assistance in documenta- tion search, and to J. Guarini for correcting the English. This study was supported by the Agence de l'Eau Adour-Garonne under contract no. 98/793.

\section{LITERATURE CITED}

Anonymous (1994) Moules et coquillages, caractérisation des consommateurs français. Centre de Recherche pour l'étude et l'observation des conditions de vie (CREDOC), observatoire des consommations alimentaires, Paris

Blanchard GF, Guarinin JM, Bacher C, Huet V (1998) Contrôle de la dynamique à cours terme du microphytobenthos intertidal par le cycle exondation-submersion. CR Acad Sci Paris 321:501-508

Blanchard GF, Guarini JM, Orvain F, Sauriau PG (2000) Dynamic behaviour of benthic microalgal biomass in intertidal mudflats. J Exp Mar Biol Ecol 264:85-100

Boutier B, Chiffoleau JF, Gonzalez JL, Lazure P, Auger D, Truquet I (2000) Influence of the Gironde estuary outputs on cadmium concentrations in the coastal waters: consequences on the Marennes-Oléron bay (France). Oceanol Acta 23:745-757

Bryan GW (1984) Pollution due to heavy metals and their compounds. In: Kinne O (ed) Marine ecology. A comprehensive, integrated treatise on life in oceans and coastal waters. Wiley-Interscience, Chichester, p 1289-1431

Bustamante P, Caurant F, Fowler SW, Miramand P (1998) Cephalopods as a vector for the transfer of cadmium to top marine predators in the north-east Atlantic Ocean. Sci Total Environ 220:71-80

Cariou-Le Gall V, Blanchard GF (1995) Monthly HPLC measurements of pigment concentration from an intertidal muddy sediment of Marennes-Oléron Bay, France. Mar Ecol Prog Ser 121:171-179

Charman K (1979) Feeding ecology and energetics of the Dark-Bellied Brent goose (Branta bernicla) in Essex and Kent. In: Jefferies RL, Davies A (eds) Ecological processes in coastal environments. Blackwood, London, p 451-465

Cochran WG (1977) Sampling techniques, 2nd edn. John Wiley \& Sons, New York

El Ghobary H, Dumon JC (1984) Contribution à l'étude des eaux interstitielles de sédiments littoraux: baie de Marennes-Oléron (S.W. France). Bull Inst Géol Bassin d'Aquitaine 36:5-19

Fish JD, Fish S (1996) A student's guide to the seashore. Cambridge University Press, Cambridge

Gonzalez JL, Jouanneau JM, Dominik J, Boutier B (1991) Particulate $\mathrm{Cd}$ and $\mathrm{Hg}$ fluxes to the sediment in the MarennesOleron Bay: origin and evolution. Environ Technol 12:209-216

Gouleau D, Jouanneau JM, Weber O, Sauriau PG (2000) Short- and long-term sedimentation on MontportailBrouage intertidal mudflat, Marennes-Oléron Bay (France). Cont Shelf Res 20:1513-1530

Goulletquer P, Héral M (1997) Marine molluscan production trends in France: from fisheries to aquaculture. In: MacKensie CL, Bunell VG, Rosenfield A (eds) The history, present condition, and future of the molluscan fisheries of North America and Europe. NOAA Tech Rep, NMFS 129, Department of Commerce, Seattle, Washington, p 137-164

Green AS, Chandler GT (1994) Meiofaunal bioturbation effects on the partitioning of sediment-associated cadmium. J Exp Mar Biol Ecol 180:59-70

Grousset FE, Jouanneau JM, Castaing P, Lavaux G, Latouche C (1999) A 70 year record of contamination from industrial activity along the Garonne River and its tributaries (SW France). Estuar Coast Shelf Sci 48:401-414 
Guarini JM, Blanchard GF, Bacher C, Gros P and 6 others (1998) Dynamics of spatial patterns of microphytobenthic biomass: inferences from a geostatistical analysis of two comprehensive surveys in Marennes-Oleron Bay (France). Mar Ecol Prog Ser 166:131-141

Guillaumont B (1991) Utilisation de l'imagerie satellitaire pour les comparaisons spatiales et temporelles en zone intertidale. In: Elliott M, Ducrotoy JP (eds) Estuaries and coasts: spatial and temporal intercomparisons. Proc 19th ECSA Symp. Olsen \& Olsen, Fredensborg, p 63-68

Héral M, Razet D, Deslous-Paoli JM, Manaud F, Truquet I, Garnier J (1984) Hydrobiologie du bassin de MarennesOléron. Résultats du Réseau National d'Observation: 1977-1981. Ann Soc Sci Nat Charente-Marit 7:259-277

Héral M, Bacher C, Deslous-Paoli JM (1989) La capacité biotique des bassins ostréicoles. In: Trodaec JP (ed) L'homme et les ressources halieutiques. Ifremer, Plouzané, p 225-259

Jouanneau JM, Boutier B, Chiffoleau JF, Latouche C, Philipps I (1990) Cadmium in the Gironde fluvioestuarine system: behaviour and flow. Sci Total Environ 97/98:465-479

Langston WJ, Zhou M (1987) Cadmium accumulation, distribution and metabolism in the gastropod Littorina littorea: the role of metal-binding proteins. J Mar Biol Assoc UK 67: 585-601

Lapaquellerie Y, Maillet N, Jouanneau JM, Maillet N, Latouche C (1995) Cadmium pollution in sediments of the Lot river (France). Estimate of the mass of cadmium. Environ Technol 16:1145-1154

Lapaquellerie Y, Maillet N, Jouanneau JM, Coakley JP, Latouche $C$ (1996) Flux de matières en suspension et de cadmium dans le Lot. Hydroécol Appl 8:173-191

Latouche C (1988) La pollution en cadmium de l'estuaire de la Gironde. Bull Inst Géol Bassin d'Aquitaine 44:15-21

Lazure P, Jégou AM (1998) 3D modelling of seasonal evolution of Loire and Gironde plumes on Biscay Bay continental shelf. Oceanol Acta 21:165-177

Leguerrier D, Niquil N, Boileau N, Rzeznik J, Sauriau PG, Le Moine O, Bacher C (2003) Numerical analysis of the food web of an intertidal mudflat ecosystem on the Atlantic coast of France. Mar Ecol Prog Ser 246:17-37

Miramand P, Bentley D, Guary JC, Brylinski JM (1993) Rôle du plancton dans le cycle biogéochimique du cadmium et du vanadium en baie de Seine orientale: premiers résultats. Oceanol Acta 16:625-632

Miramand P, Guyot T, Huet V, Pigeot J (2001a) Le cadmium dans les espèces planctoniques et suprabenthiques collectées dans l'estuaire et le panache de la Gironde. In: Elbée J (d'), Prouzet P (eds) Océanographie du golfe de Gascogne. Ifremer, Actes Colloq 31, Plouzané, p 289-296

Miramand P, Ferchaud R, Pigeot J, Caurant F, Bustamante P, Guyot T (2001b) Estimation of the Cd intake in the human dietary from the shellfish caught in the seashore of Charente-Maritime (France). Rev Med Vet-Toulouse 153: 741-746

Montaudouin (de) X, Sauriau PG (2000) Contribution to a synopsis of marine species richness in the Pertuis Charentais Sea with new insights in soft-bottom macrofauna of the Marennes-Oléron Bay. Cah Biol Mar 41:181-222

Newell RC (1979) Biology of intertidal animals. Marine ecological surveys, Faversham

Orvain F, Sauriau PG, Sygut A, Joassard L, Le Hir P (2004) Interacting effects of Hydrobia ulvae bioturbation and microphytobenthos on the erodability of mudflat sediments. Mar Ecol Prog Ser 278:205-223

Phillips DJH (1977) The use of biological indicator organisms to monitor trace metal pollution in marine and estuarine environments - a review. Environ Pollut 13:281-317
Phillips DJH, Rainbow PS (1988) Barnacles and mussels as biomonitors of trace elements: a comparative study. Mar Ecol Prog Ser 49:83-93

Pigeot J (2001) Approche écosystémique de la contamination métallique du compartiment biologique benthique des littoraux charentais : exemple du bassin de MarennesOléron. $\mathrm{PhD}$ thesis, University of La Rochelle

Purchon RD (1968) The biology of the Mollusca. Pergamon Press, Oxford

Raillard O, Ménesguen A (1994) An ecosystem box model for estimating the carrying capacity of a macrotidal shellfish system. Mar Ecol Prog Ser 115:117-130

Raillard O, Le Hir P, Lazure P (1994) Transport de sédiments fins dans le bassin de Marennes-Oléron: mise en place d'un modèle mathématique. Houille Blanche 4:63-71

Rasmussen AD, Banta GT, Andersen O (2000) Cadmium dynamics in estuarine sediments: effects of salinity and lugworm bioturbation. Environ Toxicol Chem 19:380-386

Riera P, Richard P, Grémare A, Blanchard G (1996) Food source of intertidal nematodes in the Bay of MarennesOléron (France), as determined by dual stable isotope analysis. Mar Ecol Prog Ser 142:303-309

RNO (Réseau National d'Observation) (1988) Réseau National d'Observation de la qualité du milieu marin. Dix années de surveillance 1974-1984. Document technique, volume IV, mercure et cadmium, IFREMER et Secretariat d'Etat auprès du Premeir Ministre chargé de l'Environnement, Plouzané

RNO (Réseau National d'Observation) (1995) Surveillance du milieu marin, travaux du RNO. Edition 1995, Ifremer et Ministère de l'Environnement, Nantes et Paris

RNO (Réseau National d'Observation) (2000) Surveillance du milieu marin, travaux du RNO. Edition 2000, Ifremer et Ministère de l'Aménagement du Territoire et de l'Environnement, Nantes et Paris

RNO (Réseau National d'Observation) (2004) Résultats de la surveillance de la qualité du milieu marin littoral, Départements: Charente-Maritime \& Vendée (sud), Edition 2004. Ifremer/RST.DEL.DRV.LER.PC/04/ laboratoire Environnement Ressources des pertuis Charentais, La Tremblade

Sauriau PG (1987) Les mollusques non-cultivés du bassin de Marennes-Oléron: quantification et répartition géographique des stocks. Haliotis 16:527-541

Sauriau PG, Kang CK (2000) Stable isotope evidence of benthic microalgae-based growth and secondary production in the suspension feeder Cerastoderma edule (Mollusca, Bivalvia) in the Marennes-Oléron Bay. Hydrobiologia 440: 317-329

Sauriau PG, Mouret V, Rince JP (1989) Organisation trophique de la malacofaune benthique non cultivée du bassin ostréicole de Marennes-Oléron. Oceanol Acta 12: 193-204

Sauriau PG, Pichocki-Seyfried C, Walker P, de Montaudouin X, Palud C, Héral M (1998) Crepidula fornicata (mollusque, gastéropode) en baie de Marennes-Oléron : cartographie des fonds par sonar à balayage latéral et estimation du stock. Oceanol Acta 21:353-362

Sautour B, Castel J (1998) Importance of microzooplanktonic crustaceans in the coastal food chain: Bay of MarennesOléron, France. Oceanol Acta 21:105-112

Seber GAF (1982) The estimation of animal abundance and related parameters. The Blackburn Press, Caldwell, NJ

Soletchnik P, Faury N, Razet D, Goulletquer P (1998) Hydrobiology of the Marennes-Oléron bay. Seasonal indices and analysis of trends from 1978 to 1995. Hydrobiologia 386: $131-146$ 
Sornin JM, Feuillet M, Héral M, Deslou-Paoli JM (1983) Efffet des biodépôts de l'huître Crassostrea gigas (Thunberg) sur l'accumulation de matières organiques dans les parcs du bassin de Marennes-Oléron. J Molluscan Stud Suppl 12A: 185-197

Sornin JM, Feuillet M, Héral M, Fardeau JC (1986) Influence des cultures d'huitres Crassostrea gigas sur le cycle du phosphore en zone intertidale: rôle de la biodéposition. Oceanol Acta 9:313-322

Editorial responsibility: Otto Kinne (Editor-in-Chief), Oldendorf/Luhe, Germany
Turquier Y (1989) L'organisme dans son milieu (tome 1). Précis de zoologie fonctionnelle. Les fonctions de nutrition. Doin, Paris

Wassermann JC, Dumon JC, Latouche C (1991) Importance des zostères (Zostera noltii) dans le bilan des métaux lourds du bassin d'Arcachon. Vie Milieu 41:81-86

Watson PG, Frickers PE, Howland RJM (1993) Benthic fluxes of nutrients and some trace metals in the Tamar Estuary, SW England. Neth J Aquat Ecol 27:135-146

Submitted: September 1, 2004; Accepted: July 28, 2005

Proofs received from author(s): December 15, 2005 